\title{
Demand-based problems of sustainable development of regional market of higher education services
}

\author{
Natalya Sergeevna Mushketova \\ Department of Marketing \\ Institute of Economics and Regional Management \\ Volgograd, Russia \\ nmushketova@volsu.ru
}

\author{
Svetlana Vladimirovna Fedorova \\ Department of Marketing \\ Institute of Economics and Regional Management \\ Volgograd, Russia \\ fedorovasv@volsu.ru
}

\author{
Natalia Sergeevna Polusmakova \\ Department of Marketing \\ Institute of Economics and Regional Management \\ Volgograd, Russia \\ polusmakova@volsu.ru
}

\begin{abstract}
In modern conditions the regional market of higher education services is characterized by a growing influence of general specifics of offer and demand. This trend prevails despite the social importance of this market for regional and national development, and the reduced funding for higher education. The paper outlines the specifics of demand for higher education services and for labour in the regional Volgograd market. Taking into account the revealed features will provide higher education institutions with the possibility to adapt their strategies to the changing marketing environment thus ensuring efficient sustainable development of the regional market and the region as a whole.
\end{abstract}

Keywords - market of higher education services, target segments, consumer preferences, labour market

\section{INTRODUCTION}

The research relevance consists in the fact that ensuring the strategic stability of higher education institutions in the changing regional market is largely determined by their ability to timely adapt to consumer needs and educational reforms, to form and strengthen competitive advantages, to promote brand at the regional, national and world markets. In this connection, there is a need to study the current demands of the regional market of education services, to identify consumer segment for universities, to choose an adequate market position and to develop (or adapt) the corresponding marketing strategy of the university.

Working out a marketing strategy of the university in the regional market of higher education services is based on identifying all target segments of the market and consumer preferences for educational services.
Analyzing the demand for educational services in the regional market (using the example of Volgograd State University - VolSU) allows distinguishing three key target segments: individual consumers (individuals), legal entities of commercial or non-commercial sphere (enterprises and legal institutions), and public sector (national, regional and local authorities). Each segment has its own specific features, which should be taken into account in the process of developing a marketing strategy in the regional market and promoting the brand of VolSU.

For example, the market of enterprises and institutions is characterized by the professional structure of educational strategies for employees, an adequate reaction to structural transformations in the economic development of the region, a fairly rapid change in demand for educational services, taking into account the current situation in the regional labour market.

The public sector is attractive for higher education institutions due to large scale of demand for relevant training programs and guaranteed consumption. However, the segment of individual consumers remains a dominant one in the regional market of educational services. It is characterized by a variety of motives, preferences and career priorities of consumers.

The research purpose consists in the identification of consumer preferences in relation to the educational services of the Volgograd State University with a view to developing relevant educational products demanded by the regional labour market. 


\section{MATERIALS AND METHODS}

Theoretical aspects of the research are substantiated through general scientific approaches: dialectic, historical and logical, structural and functional; practical guidelines are worked out on the basis of traditional methods (segmentation, prioritization), as well as up-to-date methods of market research, such as case study, monitoring, expert estimation, graphical review technique, content analysis and other methods

\section{RESULTS AND DISCUSSION}

Real-life practice and experience of leading educational institutions clearly demonstrate the key factor of efficient activity of the higher education institution in modern demographic, socio-economic and political-legal conditions. This factor consists in the use of a marketing approach in management. The development of theoretical, methodological and applied aspects of this approach will allow regional universities to develop a marketing strategy on a scientifically grounded basis of activities' adaptation to the rapidly changing market environment, and as a result, to effectively present their services in competitive conditions.

In 2014 and in 2017 the marketing surveys were carried out to reveal consumer motives and preferences of pupils of $10-11^{\text {th }}$ grades of schools of Volgograd and the Volgograd region concerning higher professional education. In 2014, 415 pupils were selected by judgemental sampling; in 2017 - 280 pupils [1].

The results of 2014 survey (questionnaire) of pupils indicate that higher education has become an instrumental value, a necessary and indispensable condition for building a successful career, earning decent wages and achieving a high social status. Thus, $84 \%$ of the pupils surveyed announced their intention to enter a university, $8 \%$ were going to enter a college, and the rest either did not make a decision, or intended to work after leaving school.

The obtained regional data confirms the all-Russian reality - the majority of school graduates have a firm goal to get a Higher Education Diploma. In the current economic structure, high-paid industries employ graduates of higher education institutions, since the recruitment system of such industries is based on connections and recommendations. Therefore, the professionalism of candidates is not considered to be the criterion of employment. This situation does not stimulate potential consumers to obtain a more qualitative education, because they think of their future job as a matter of connections. This trend actually eliminates all efforts made by the state to restore the primary and secondary levels of professional education and to cope with the shortage of trades.

Respondents' answers with regard to the choice of a university showed that the top three universities of the Volgograd region include Volgograd State University (36\%), Volgograd State Technical University (21\%), Volgograd State Socio-Pedagogical University (17\%). The Volgograd State Medical University $(15 \%)$ ranks $4^{\text {th }}$ and takes a special place in the respondents' consumer choice.
Analysis of applicants' preferences in the choice of training programs shows that a quarter of respondents choose economic profile, and the fifth part - jurisprudence and law (Fig. 1).

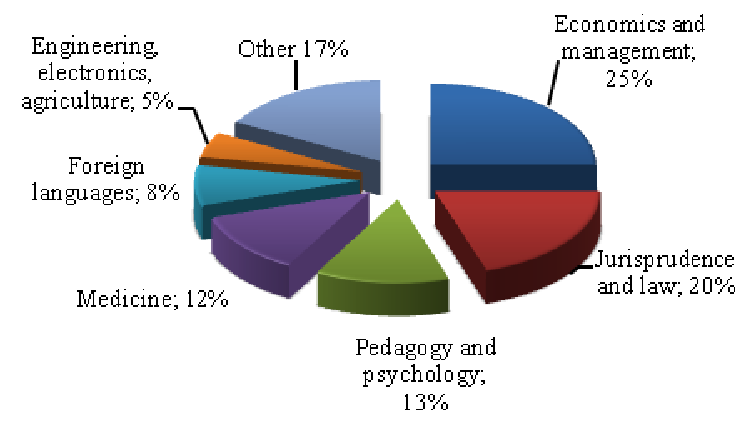

Fig. 1. School graduates' preferences for training programs.

The obtained regional map of school graduates' preferences reflects the all-Russian trend - more than half of future students opt for economy and law, and such trend will dominate until the structure of the Russian economy changes, that is, at least in the medium term.

The questionnaire offered the pupils a list of factors that influenced their decision on the choice of a university. The results are shown in the following ranking (Fig. 2).

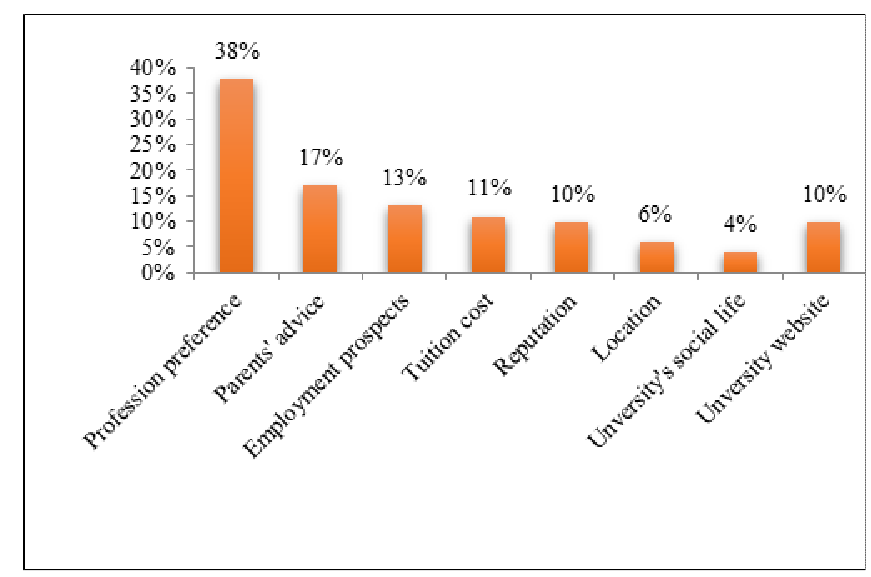

Fig. 2. Factors influencing the choice of a university.

As can be seen from the diagram, the applicants' choice is mainly determined by profession preference, which is in its turn conditioned by the current conjuncture of the regional labour market and employers' demands. The opinion of applicants and their parents on the choice of a university and profession coincides in the most demanded ones.

In addition to the mentioned factors, the behavior of consumers of higher education services in the region is also influenced by mostly negative perception of the economic situation and its prospects in the country as a whole; level and rates of economic development of the region; an imbalance in wages and qualification of employees in the region. Respondents from families with low incomes prefer the highly demanded professions, intending to use the higher education 
as a "social elevator". Correspondingly, the higher the incomes of respondents' families, the less the motivation to get a profession demanded in the regional market [2].

In response to a question about the parents' willingness to pay for tuition at a university, $32 \%$ of respondents confirmed their parents' $100 \%$ intention to pay for higher education; $27 \%$ of parents are willing to pay at the cost of refusal to purchase expensive goods (car, apartment, etc.); and $28 \%$ of parents intend to pay for education in austerity. And only parents of $13 \%$ of respondents do not intend decidedly to pay for education, preparing children for a budget option. In other words, the absolute majority of parents are ready to pay for their children's education in universities, since a Higher Education Diploma is now an imperative requirement for admission to a well-paid job.

To study the dynamics of the revealed trends in 2017, we carried out a second survey of target consumers of higher education services - pupils of $10-11^{\text {th }}$ grades of schools of Volgograd and the Volgograd region. The sampling amounted to 280 people.

The research results are almost identical to the results of 2014 survey: the preferences of applicants regarding the choice of universities and training programs have not changed. The most important factors influencing the decision include the availability of a profession demanded in the regional labour market and prospects for future employment.

Since the demand in the market of higher education services is derived from the demand of economic agents of the regional labour market for young university graduates, we carried out an analysis of the specific features of demand in the labour market. So, in order to determine the needs and demands of regional entrepreneurs in relation to graduates, 243 top managers of the Volgograd region enterprises were interviewed on the issue in 2014. $76 \%$ of respondents answered negatively to the first question: "Would you hire a university graduate without work experience?".

Employers pointed out the following requirements for applicants as the most important: professionalism (90\%), literacy $(65 \%)$, social skills $(56 \%)$, diligence $(54 \%)$, etc. (Fig. $3)$.

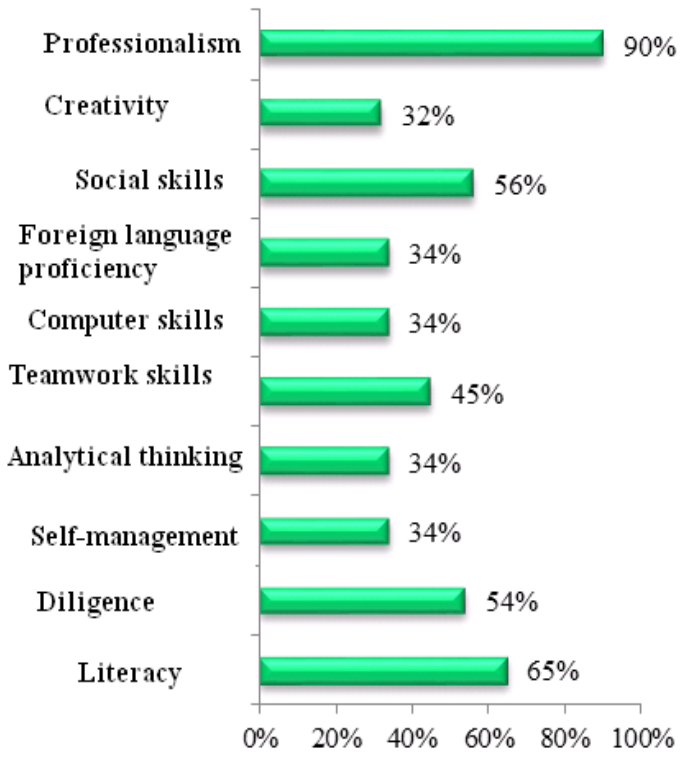

Fig. 3. Ranking of emploeyrs' requirements to university graduates.

When hiring graduates, managers often face the following negative characteristics: lack of competence $(80 \%)$, professional passivity (54\%), arrogance (54\%), lack of motivation for long-term cooperation (34\%). More than half of managers $(56 \%)$ are ready to invest in continuing education of their employeers, while $44 \%$ do not intend to.

The analysis has shown that business (labour market) preferences in relation to universities are identical to the demands of consumers in the market of educational services. The choice of both segments coincides in the already mentioned Volgograd State University, Volgograd State Technical University, Volgograd State Socio-Pedagogical University, and also in the Volgograd branch of Russian Presidential Academy of National Economy and Public Administration. Thus, top five leaders are represented by the classical universities of Volgograd.

The interesting fact is that employers rely mostly on recommendations $(43 \%)$ as a source of information about applicants. This confirms the representations of pupils and students about the recruitment mechanisms in the region based on connections. A quarter of applicants are chosen according to $\mathrm{CV}$ information placed on specialized websites $(25 \%)$ and ad sites (18\%); and only $13 \%$ of employers turn to employment centers and job fairs. At the same time, none of the respondents considers the universities' websites as a source of information about applicants.

Thus, the regional trend of employer preferences fully reflects the all-Russian trends. Barriers in the employment process of young specialists are due to their relatively low competitiveness in the regional labour market, which is most often associated with the lack of professional knowledge and skills, the lack of qualifications and skills required by the employer. The priority is given only to qualified professionals with work experience.

The current situation is exacerbated by the refusal of a significant number of employers to invest in continuing 
education of young newly employed specialists. According to employers, graduates are passive, not willing to work and build career. They show excessive demands and intention to find a higher paid job at a convenient opportunity, which diminished the opportunity for long-term cooperation.

The results of marketing research into the regional labour market let reveal the key problems of its interaction with the market of higher professional education.

Firstly, today there is a significant disproportion between the structure of students' graduation and the structure of labour needs in the regional labour market. At the same time, the largest staff shortage is peculiar of those sectors which are the most promising from the viewpoint of innovative development of the country or a region, but they are not attractive enough from the viewpoint of graduate's financial interest.

Secondly, the competencies and qualifications of graduates do not fully meet the needs of employers. The status of university graduates in the regional labour market is characterized by a high percentage of unemployment, an increase in the time lag for unemployment at the initial stage of a professional career: after 5-6 months of job search, the chances of employment are drastically reduced as a young specialist gradually loses their skills. Besides, the lack of employment period becomes an insurmountable obstacle in finding a job. Accordingly, the labour potential of young specialists is not used to the full extent, the renovation and rotation of personnel are not carried out in many sectors which need it.

Thirdly, a university graduate cannot actually meet all the employer's requirements due to substantial differentiation of such requirements in different enterprises. This fact determines the need for further training of young specialists after recruitment. A low level of wages in enterprise is associated with the risk of an employee's leaving for a higherpaid job after training. This keeps the employer from investing in professional training of employees.

Fourthly, the professional competences are understood differently in the labour market and in universities. Professors of higher school define competence as student's potential, taking into account knowledge and skills acquired in the process of mastering specific academic disciplines. Employers consider competence as the ability to act effectively [3]. Obviously, this contradiction in approaches to understanding the competence between the theoreticians of higher professional education system and labour market practices is currently insurmountable.

Fifthly, by the present time, employers have not yet formed civilized mechanisms for search, selection and recruitment of future employees. According to all-Russian research, informal channels of interaction with higher education institutions prevail in Russian companies. In most cases, heads of personnel services of enterprises address directly to familiar directors of institutes, managers or professors from specific departments of profile universities in the region with a friendly request to recommend suitable candidates.
Over the recent years $80 \%$ of all the vacant jobs in employment centers have been blue-collar ones. This complicates the interaction of labour markets and educational services of universities. The growth of demand for service personnel and the simplest blue-collar jobs is a direct consequence of the reduction in the number of students in the primary and secondary levels of professional education. In accordance with the ranking of the 14 most demanded professions, shop assistants, cashiers, drivers and builders rank top. Lower positions in the ranking are occupied by engineers, doctors and teachers.

According to monitoring data for 2015, the highest level of tension coefficient in the labour market (excessive supply) characterized such professions as economists, financial experts, accountants - 16; assistant administrators, record managers - 12; agricultural specialists - 9; lawyers -8 . Coefficient below 1 (excessive demand) characterized junior and medium-level medical personnel (0.5); teachers (0.4); locksmiths (0.4); builders (0.3); gas electric welders (0.2); doctors $(0.1)$. In general, the need for specialists with higher professional education in the short term will make $19 \%$ of the total demand; and the need for specialists with primary professional education $-66 \%$ [4].

The labour market is also characterized by deprofessionalization which consists in both the reduced demand for highly skilled occupations, and the loss of a previously acquired profession. The more people acquire a profession that is not in high demand in the labour market, the higher the level of deprofessionalization. Experts note that about half of young specialists with higher education have to change their specialization, sometimes drastically. According to the survey carried out by Higher School of Economics, particularly by V. Gimpelson and R. Kapelyushnikov, only $79 \%$ of medical personnel, $67 \%$ of IT specialists, $59 \%$ of lawyers, and $36 \%$ of engineers work in their specialization [5].

In today's Russian public opinion, not working in one's specialization is a normal phenomenon, peculiar even of developed countries. If earlier in Russia job advertisements specified information about the required profession and qualifications, the nature and degree of complexity of the proposed job, now such advertisements have blurred general phrases - office work, higher education, discipline and social skills; office work without age restrictions, higher education; office work, income from ..., higher education. Moreover, such ads do not contain information about the required profession and qualifications, type of labour. The content analysis of such ads allows us to conclude that the qualification is no longer of the same importance for the labour market, and employers give preferences for employees' basic communication skills and ability to self-management.

\section{CONCLUSION}

The analysis of consumer preferences in the market of educational services of regional universities showed a high differentiation of consumer demand, motives, priorities and problems. Higher education is seen by consumers as a utilitarian tool for building a successful career and successful socialization. Students see the priority in the skilful use of the 
"necessary connections" mechanism, rather than in the quality of the higher education obtained.

The analysis of consumer preferences from the viewpoint of the regional labour market demand shows that the business community also treats higher education exclusively through the prism of economic interests.

On the one hand, the educational services of universities should be rendered taking into account the needs of regional business. On the other hand, excessive interest in applied aspects is a dangerous trend, which can lead to neglect not only for certain non-applied disciplines, but even for entire training programs that do not have a clearly expressed market demand, but make a great contribution to science and culture of the country. That is why it is necessary to ensure the large scale and diversity of business structures involved in cooperation: from public sector to medium and small businesses. To form an efficient and civilized labour market, the demand must be predictable for several years ahead, and the proposal should be as flexible as possible. These conditions seem to be easy to achieve if the interests of all market participants are coordinated: employers, employees, higher education institutions and authorities. At the same time, higher professional education should not go in the wake of the existing demand in the labour market, in fact it should develop in accordance with the principle of anticipatory need. Actually, in order to ensure the future progressive development of the country, the society must possess "pure" intellectual potential, completely free from the demand of today's employers.

\section{References}

[1] Timofeeva G.V., Mushketova N.S. Rynok obrazovatelnykh uslug vuzov: analiz predlozheniya i sprosa [The market of higher education services: an analysis of supply and demand]. Ekonomicheskiy analiz: teoriya i praktika [Economic analysis: theory and practice], 2014, no. 27 (378), pp. 44-55.

[2] Shevchenko D.A. Konkurentosposobnost vuzov. Tekhnologiya sozdaniya, soprovozhdeniya i prodvizheniya saita vuza [The competitiveness of higher education institutions. Technology of development, maintenance and promotion of the university website]. Available at: http://shevchenko.rggu.ru/?p=404.

[3] Propp O.V. Vzaimodeystvie sfery vysshego obrazovaniya i regionalnogo rynka truda na osnove kompetentnostnogo podkhoda [The Interaction of the Higher Education Sphere and the Regional Labor Market on the Basis of the Competence-Based Approach]. Rossiyskoe predprinimatelstvo [Russian Journal of Entrepreneurship], 2011, no. 12 (10), pp. 38-42.

[4] Kochetov A.N. Professionalnoe obrazovanie i rynok truda: problemy vzaimodeystviya [Professional education and labor market: Interaction issues]. Sotsiologicheskie Issledovaniya [Sociological Studies], 2011, no. 5, pp. 82-90.

[5] Avraamova E.M. Rynok truda i sistema obrazovaniya: trudnosti perevoda signalov [Labor market and educational system]. Obshchestvennye nauki i sovremennost [Social sciences and modernity], 2011 , no. 3, pp. 51-61. 